\title{
Shelf-edge delta and slope deposition in the Upper Callovian - Middle Oxfordian Olympen Formation, East Greenland
}

\author{
Michael Larsen and Finn Surlyk
}

The Upper Bajocian - Upper Volgian succession of the Jameson Land Basin in East Greenland forms an overall transgressive-regressive cycle. The Upper Callovian - Middle Oxfordian Olympen Formation represents the first regressive deposits after maximum flooding in the Middle to early Late Callovian. The formation was deposited during two southwards progradational phases separated by a major drowning event in the Early Oxfordian. The first phase was marked by incoming of massive slope and base-of-slope sand (Athene Member), but the delta front and top did not reach the area of present-day exposure. The second phase was initiated by deposition of a thick mud succession (Hades Member) indicating that the delta had shifted far to the north during the drowning event. Southwards progradation of the delta was heralded by gully erosion and the deposition of lenticular bodies of massive slope sand; on this occasion, medium- and largescale cross-bedded sand of the delta front and top (Zeus Member) reached the area.

The boundary between Middle-Upper Callovian mudstones in the upper part of the underlying Fossilbjerget Formation and the Upper Callovian Athene Member sandstones formed at the turn-around point between sea-level rise and fall. The Athene Member sandstones are interpreted as an undifferentiated falling stage - lowstand systems tract and span a sequence boundary. The top of the Athene Member is the basinal correlative of the transgressive surface. The basal few metres of the overlying Hades Member mudstones represent the transgressive systems tract and a level with organic-rich mudstones is interpreted to represent the maximum flooding zone. The remainder of the Hades Member and the slope sandstones are assigned to the highstand systems tract. The succeeding cross-bedded delta front sandstones of the Zeus Member are placed in the falling stage systems tract and their sharp base is interpreted as a marine regressive surface of erosion. Comparison of this history with published sea-level curves suggests that the short term changes may be eustatic in origin including the Middle Callovian maximum flooding (K. jason - lower P. atbleta Chronozones), Late Callovian regression (P. atbleta - Q. lamberti Chronozones), latest Callovian - Early Oxfordian flooding (Q. mariae - C. cordatum Chronozones) and late Early - Middle Oxfordian regression (C. densiplicatum Chronozone).

Keywords: East Greenland, Jameson Land Basin, Middle-Upper Jurassic, sedimentology, lithostratigraphy, sequence stratigraphy, shelf-edge delta, slope gullies, massive sandstones, sediment gravity flow, sea-level curve

M.L., Geological Survey of Denmark and Greenland, Geocenter Copenhagen, Øster Voldgade 10, DK-1350 Copenhagen K, Denmark. E-mail: mil@geus.dk

F.S., Geological Institute, University of Copenhagen, Geocenter Copenhagen, Øster Voldgade 10, DK-1350 Copenbagen K, Denmark. 
Shelf-edge deltas and their associated slope/base-of-slope deposits are becoming increasingly well-known, especially from the passive margins of the Gulf of Mexico and the western Mediterranean (Suter \& Berryhill 1985; Suter et al. 1987; Tesson et al. 1990, 1993; Sydow \& Roberts 1994; Gensous \& Tesson 1996; Henriksen \& Weimer 1996). In this study we describe Upper Callovian - Middle Oxfordian sandy shelf-edge deltas and slope gravity flow deposits formed during the early stages of Jurassic rifting in the East Greenland basin. In the Jameson Land Basin, rifting was initiated in the Early Bajocian, reached a climax in the Volgian and waned in the earliest Cretaceous. The resulting marine Middle - lower Upper Jurassic rift succession forms an overall transgressive-regressive cycle with a duration of $c .30 \mathrm{Ma}$. The basin axis was oriented north- south, deepening southwards. Middle Jurassic sediment influx was from the north and transport was mainly axial towards the south resulting in a marked north-south grain-size gradient with a thick succession of shallow marine sandstones in the northern part of the basin passing into thinner offshore mudstones towards the south.

The aim of the study is to describe the development of the forestepping Late Callovian - Middle Oxfordian shelfedge delta and slope system constituting the Olympen Formation of the Jameson Land Basin (Surlyk et al. 1973; Surlyk 2003, this volume, fig. 5). It marks the initiation of the stepwise Late Jurassic regression after Middle to early Late Callovian maximum flooding of the basin.

\section{Ice \\ $\square$ Quaternary \\ Olympen Formation

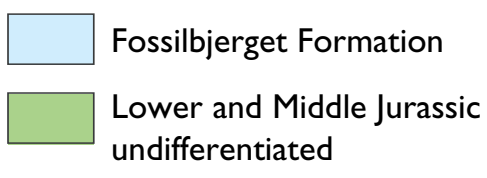

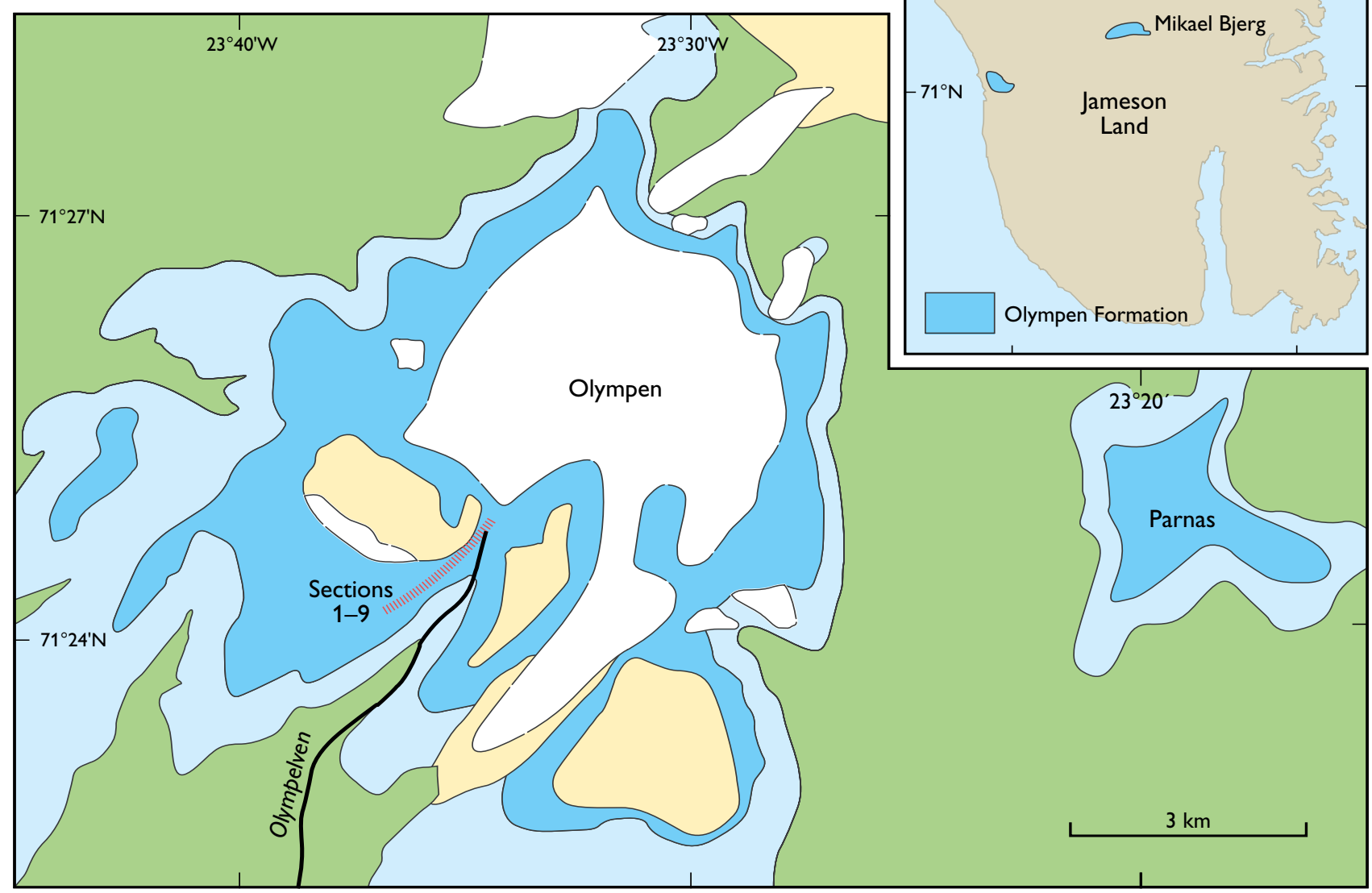

Fig. 1. Map showing the distribution of the Upper Callovian - Middle Oxfordian Olympen Formation in Jameson Land and place names mentioned in the text.
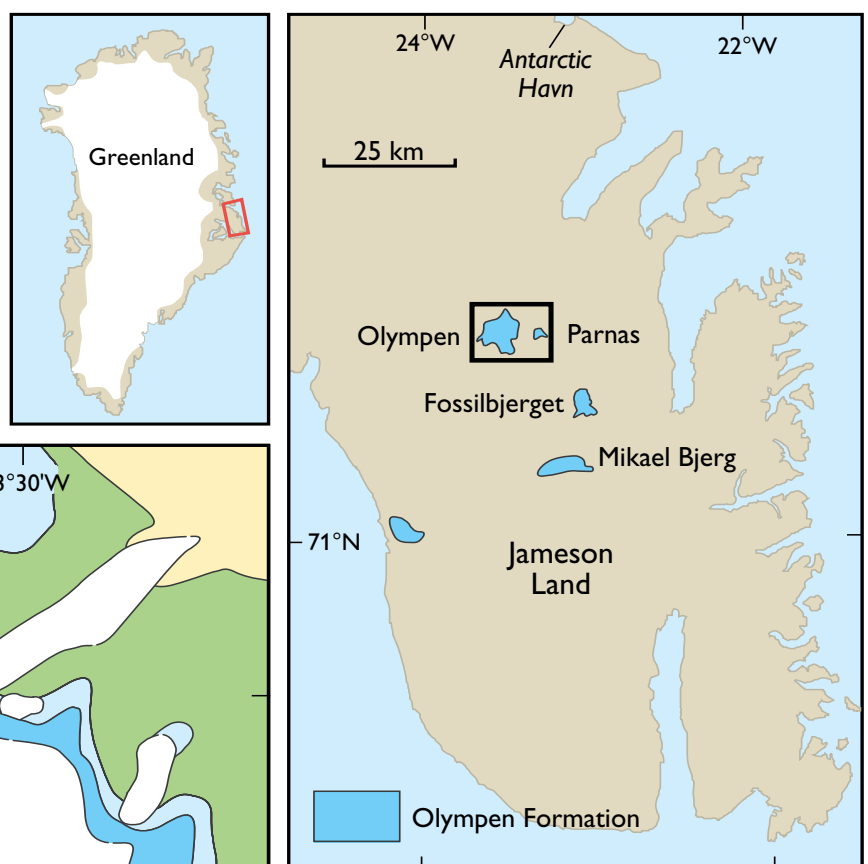


\section{Geological setting}

The onshore part of the Late Paleozoic - Mesozoic rift basin of East Greenland is about $600 \mathrm{~km}$ long and about $200 \mathrm{~km}$ wide at the southern end where the Jameson Land Basin is located (Fig. 1). The basin was uplifted in Tertiary times and the Mesozoic succession is excellently exposed.

In East Greenland, the Early Jurassic period was tectonically quiescent and deposition was restricted to the Jameson Land Basin, whilst the northern parts of the rift basin were emergent. Marine communication between the Boreal Sea and the Tethys Ocean was effectively obstructed at the end of the Early Jurassic by uplift of the North Sea dome (Surlyk et al. 1973; Underhill \& Partington 1994). Distinct faunal provinces rapidly developed and a separate ammonite-based biostratigraphic scheme is used for the Bajocian - Lower Callovian interval in the Boreal Realm (Callomon 1993; 2003, this volume).

A combination of Bathonian-Callovian eustatic sealevel rise, domal deflation and erosion, and onset of the important Middle-Late Jurassic rift phase led to gradual resumption of the north-south marine connection from mid-Callovian times. Although there was still a marked faunal provincialism in the Oxfordian-Kimmeridgian, the degree of faunal overlap allows good correlation between East Greenland and Europe.

Maximum flooding of the Jameson Land Basin took place in the Middle to early Late Callovian when the Middle Jurassic sand-dominated system was completely drowned and offshore muds were deposited throughout the basin. Rifting increased in the OxfordianKimmeridgian and reached a climax in the Volgian, contemporaneous with the onset of a Late Jurassic eustatic sea-level fall. This led to a punctuated Late Jurassic regression and by Late Volgian times, deltaic deposits had prograded to the southernmost end of Jameson Land.

During the early part of the rift phase, in BajocianBathonian times, the sea floor was essentially flat and differentiation into shelf, slope and basin was not developed. However, continued southwards axial sediment transport resulted in higher sedimentation rates and preferential sand deposition in the northern part of the basin, whereas the southern part mainly received mud. This led to the gradual development of a northern shallow marine shelf passing southwards into an east-west striking ramp with an incipient slope grading into a deeper-water basin towards the south.

Two important regressive phases separated by a major drowning event took place in the Late Callovian and Middle Oxfordian, respectively, and southwards axial progradation of shallow marine and deltaic sands reached central Jameson Land. A marked slope was formed in front of the two forestepping successions, and well-developed slope and shelf-edge delta deposits are preserved on several mountain tops in central Jameson Land (Fig. 1).

The slope facies are composed of dark grey mudstones and massive, sediment gravity flow sandstones. Similar facies types are known from the slightly younger Upper Oxfordian - Volgian Hareelv Formation in southern Jameson Land (Surlyk 1987) but this latter unit has experienced major post-depositional modification characterised by syndepositional loading structures and evidence of post-burial liquefaction and intrusion of sands into the adjacent and overlying mud (Surlyk \& NoeNygaard 2001). Post-Middle Oxfordian shelf-edge deltas are only preserved in the Middle-Upper Volgian part of the succession in southernmost Jameson land, due to present-day erosion levels. The shelf-edge delta and slope deposits of the Late Callovian and Middle Oxfordian progradational phases constitute the Olympen Formation of Surlyk et al. (1973; Fig. 2).

\section{The Olympen Formation}

\section{Stratigraphy}

The Olympen Formation was defined by Surlyk et al. (1973) for an Upper Callovian - Middle Oxfordian tripartite sandstone-mudstone-sandstone succession forming the youngest pre-Quaternary sedimentary unit in central Jameson Land (Fig. 1). The formation is divided into three members following the revised lithostratigraphic scheme for the Jurassic of East Greenland, provisionally introduced by Surlyk (2003, this volume, fig. 5). It consists of: (1) a lower unit of massive, fineto medium-grained sandstones intercalated with subordinate, laminated, dark silty mudstones and finegrained laminated sandstones termed the Athene Member, (2) a middle unit, termed the Hades Member, of dark silty mudstones which passes upwards into sandy mudstones intercalated with lenticular bodies of massive sandstones and (3) an upper unit of massive or large-scale cross-bedded, medium- to coarse-grained sandstones with subordinate intercalations of silty mudstones termed the Zeus Member (Figs 2, 3; Surlyk 2003, this volume, fig. 5).

The complete thickness is not known as the formation forms the top of the succession in central Jameson 


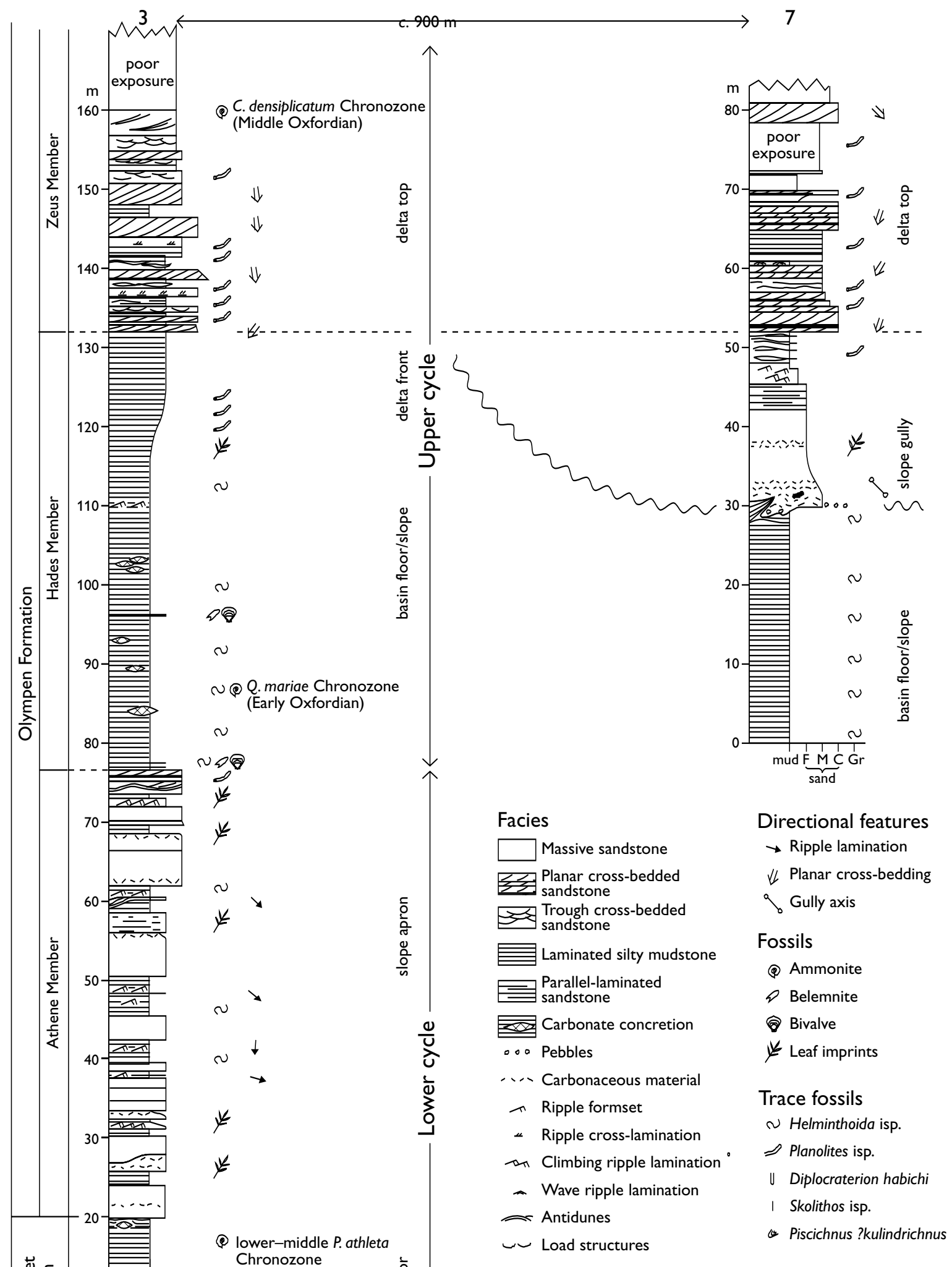

Fig. 2. Vertical sections including the type section (left) of the Olympen Formation at the head of the river Olympelven. The Olympen Formation overlies mudstones of the Fossilbjerget Formation. Note the tripartite lithostratigraphic subdivision of the Olympen Formation into lower and upper sandstone-dominated units of the Athene and Zeus Members, respectively, separated by the middle mudstone-dominated Hades Member. The upper boundary is not exposed as the formation forms the summit of the mountains in central Jameson Land. 


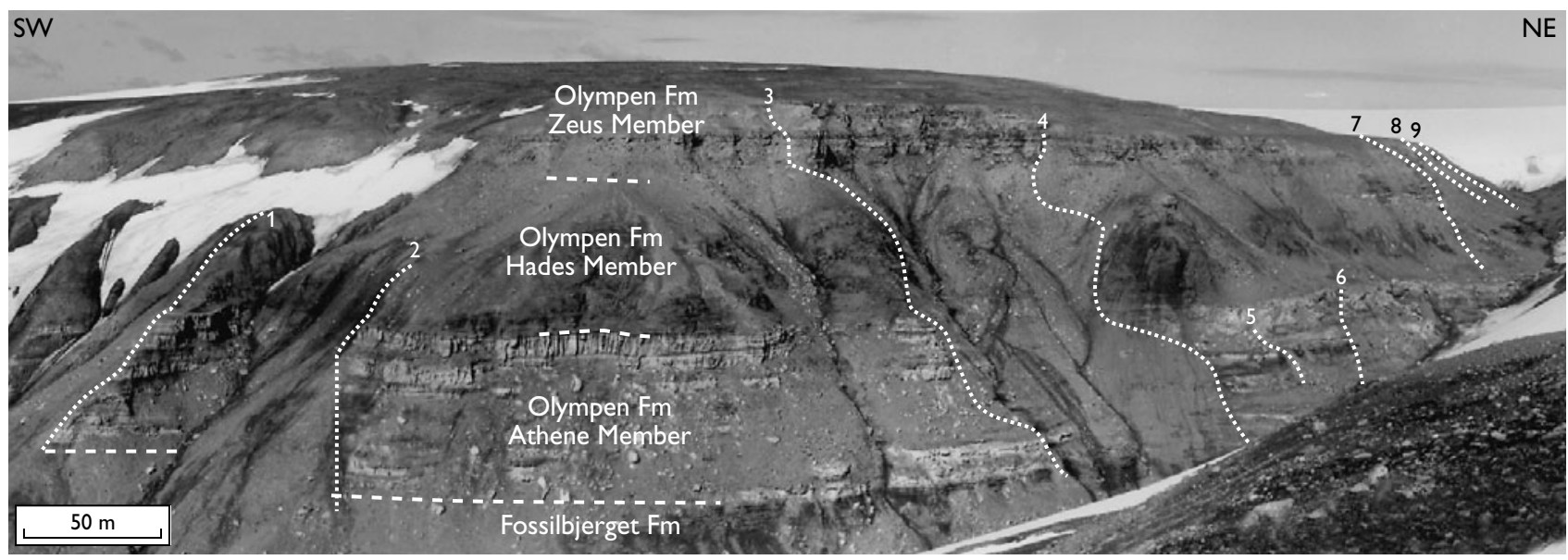

Fig. 3. Photomosaic of the type locality at Olympelven on the south side of the glacier-covered mountain Olympen. The positions of the measured vertical sections (1-9) are shown (see also Fig. 4).

Land. The type section (Figs 2-4, section 3) at the top of the Olympen mountain measures $150 \mathrm{~m}$, but the thickness in this area may reach $250 \mathrm{~m}$, the upper part being poorly exposed below scree, till and ice. At the Parnas, Fossilbjerget and Mikael Bjerg mountains, the formation is $300 \mathrm{~m}, 250 \mathrm{~m}$ and $200 \mathrm{~m}$ thick, respectively; further south, in the Hurry Inlet region, it wedges out completely or is only represented by a few metres of mudstones (Surlyk 1991).

The Olympen Formation conformably overlies fossiliferous Middle and lower Upper Callovian mudstones of the Fossilbjerget Formation of Surlyk (2003, this volume, fig. 5; equivalent to the Fossilbjerget Member of Surlyk et al. 1973). The base of the Olympen Formation is defined by the base of the first thick massive sandstone in the succession (Fig. 2). The age of the lower boundary of the formation generally becomes younger from north to south. At the type section, ammonites of the Middle Callovian K. jason Chronozone occur $20 \mathrm{~m}$ below the base of the Olympen Formation and the lower Upper Callovian P. athleta Chronozone is represented $13 \mathrm{~m}$ below the base (Fig. 2). Ammonites from the lower-middle $P$. athleta Chronozone (Kosmoceras (Zugokosmokeras) cf. proniae Teisseyre) occur $3 \mathrm{~m}$ below the base, close to the type section, and have also been found $15 \mathrm{~m}$ above the base north of Olympen (Figs 1, 2; Birkelund et al. 1971). At Mikael Bjerg, the upper part of the Fossilbjerget Formation yields ammonites of the lower P. athleta Chronozone (Longaeviceras keyserlingi Sokolov) in contrast to the northernmost outcrops at Antarctic Havn where the same ammonite fauna occurs in the lowermost member (Athene Member) of the Olympen Formation (Callomon 1993). The mid- dle mudstone-dominated Hades Member has yielded ammonites of the Lower Oxfordian Q. mariae Chronozone, C. scarburgense Subzone (Surlyk et al. 1973; Callomon 1993). Scattered finds of ammonites from the upper sandstone-dominated Zeus Member indicate the presence of the Middle Oxfordian $C$. densiplicatum Chronozone, C. vertebrale Subzone (Birkelund et al. 1971; Callomon 1993).

The base of the Olympen Formation is located just above a regional drowning surface at the turn-around point between the backstepping Upper Bajocian Upper Callovian Pelion-Fossilbjerget Formation couplet and the forestepping Upper Callovian - Middle Oxfordian Olympen Formation (Surlyk 1991; 2003, this volume). The Olympen Formation records two marked progradational phases, one in the Late Callovian ( $P$. atbleta Chronozone) and one in the early Middle Oxfordian ( $C$. densiplicatum Chronozone), separated by a drowning event in the Early Oxfordian (Q. mariae Chronozone).

\section{Sedimentary facies}

Recent field work has demonstrated that the Upper Bajocian - Upper Volgian package of the Jameson Land Basin forms an overall transgressive-regressive cycle and that massive base-of-slope sandstones are developed in front of stacked, forestepping shelf-edge deltas from the Late Callovian and through the rest of the Jurassic period (Surlyk 2003, this volume). The facies of the Olympen Formation clearly fall within this spectrum of shelf-edge delta and slope deposits and are described below. 

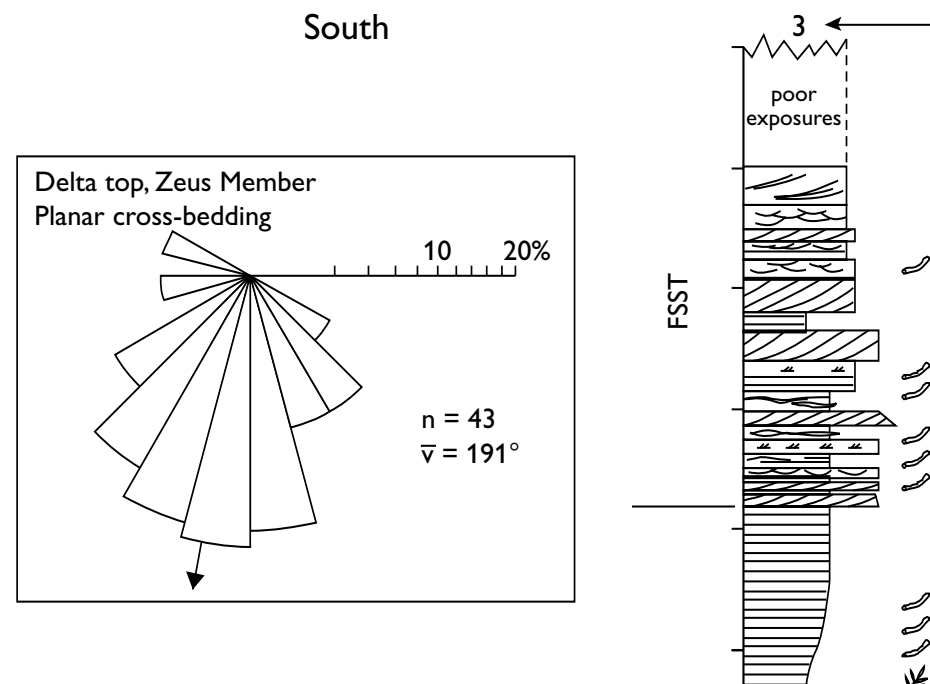

$300 \mathrm{~m}$

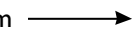

4

$150 \mathrm{~m}$
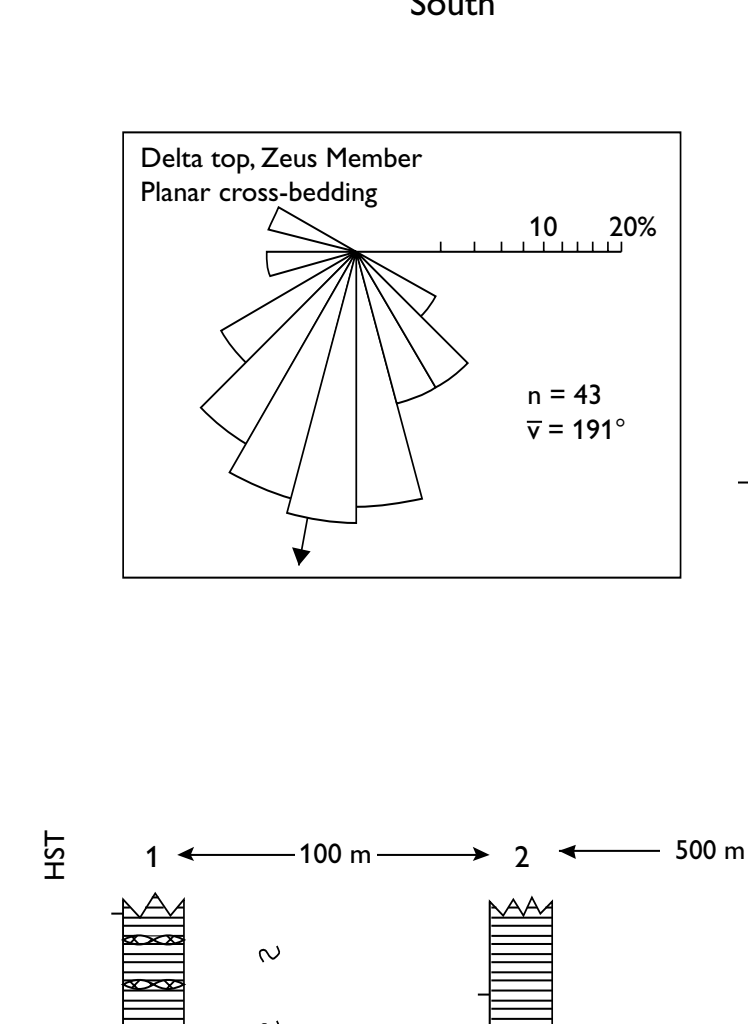

$500 \mathrm{~m}$
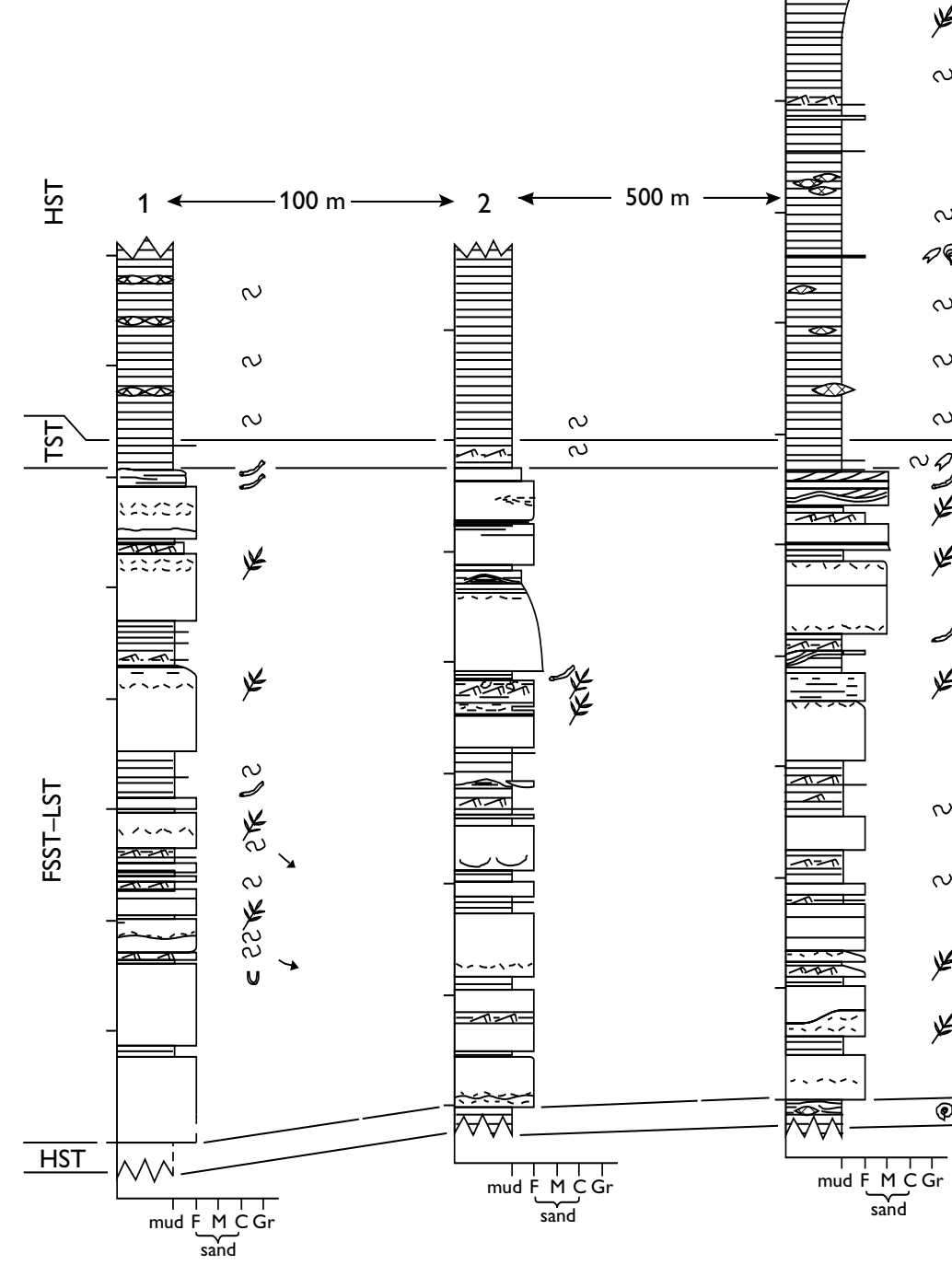

$\sim$
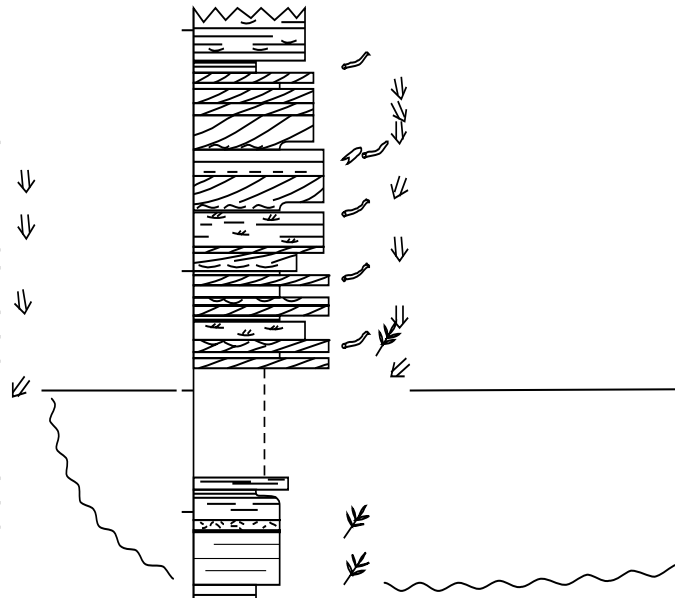

$\sim$

$\sim$

$\sim$

$\sim$

$\sim$

$\approx$

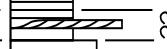

$\underline{E}$

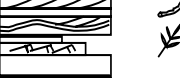

*

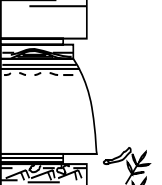

"1.⿲丿丨

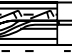

$\overline{\overline{\bar{T}}}=$
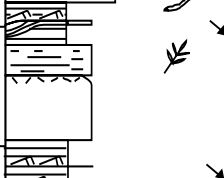

त्र

$\sim y$

त=त्र

$\sim \downarrow-\frac{}{\sqrt{n(1)}}$

N
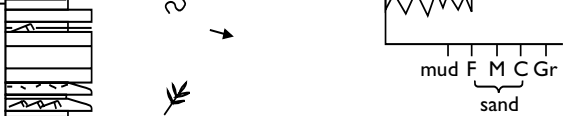

ㄴ.:

政

Q

mud F M C Gr

sand

Fig. 4. North-south correlation panel of the Olympen Formation at the type locality. Sheet-like beds of massive sandstone deposited from sediment gravity flows dominate the Athene Member. The Hades Member consists of silty mudstones with lenticular bodies of gravity flow sandstones (sections 7-9) and is overlain by cross-bedded, coarse-grained sandstones of the Zeus Member. The succession represents two cycles of slope and shelf-edge delta progradation. For legend, see Fig. $2 ; \mathbf{n}=$ number of measurements, $\mathbf{\mathbf { v }}=$ vector mean. 


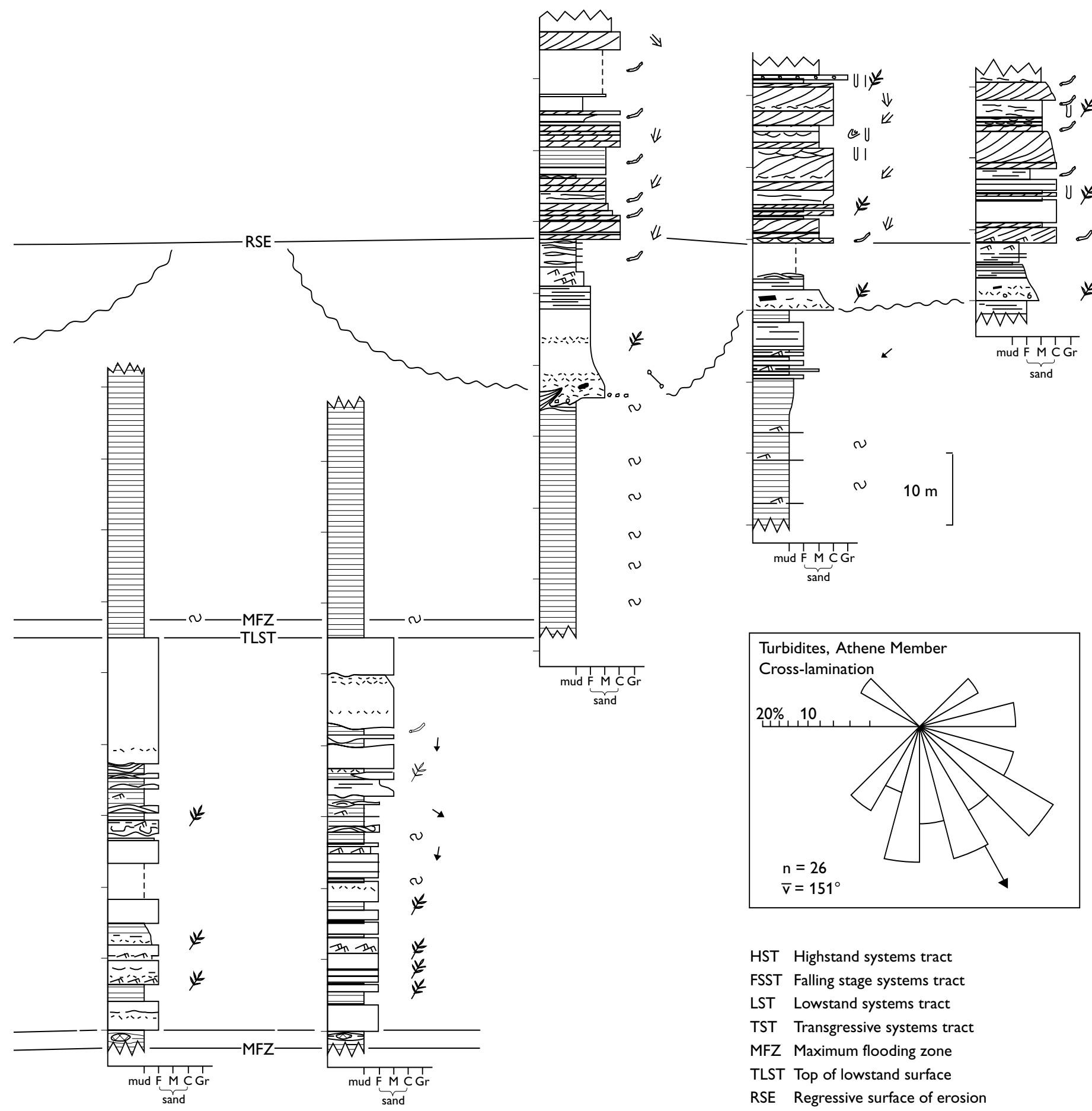




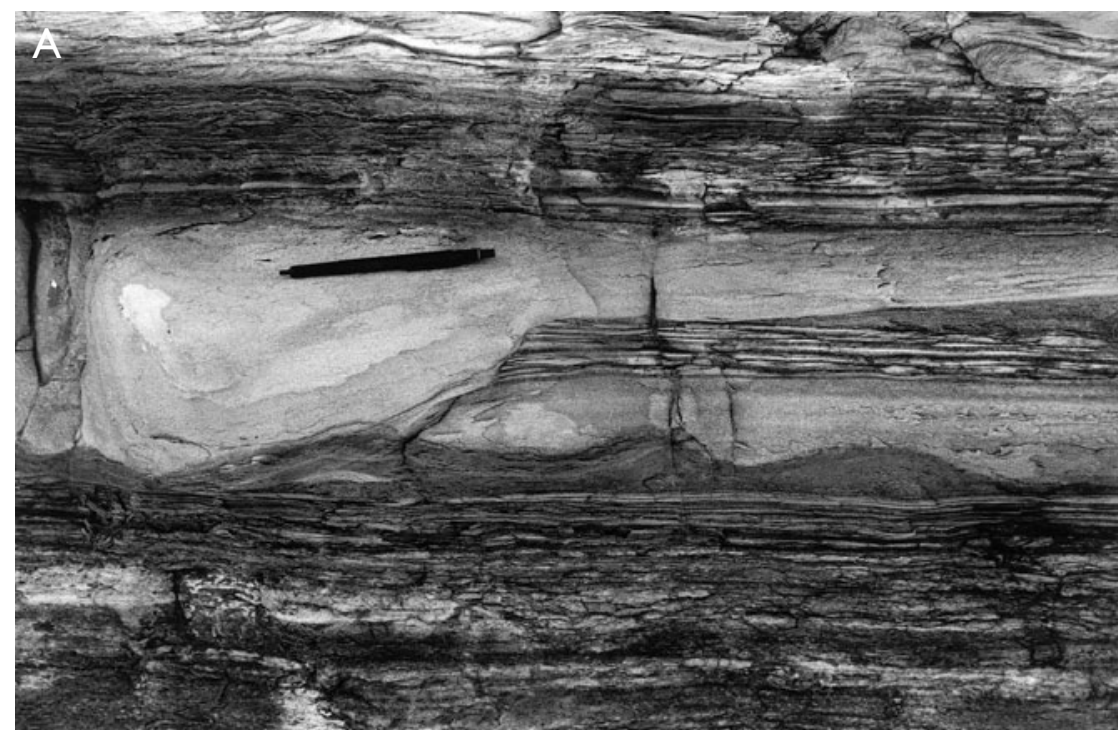

Fig. 5. A: Heterolithic mudstones and fine-grained sandstones (facies 1) intercalated with thin-bedded, massive sandstones (facies 4). The upper massive sandstone is strongly erosional and probably represents a local cut-and-fill. Athene Member, section 4. Pencil is 14 $\mathrm{cm}$ long. B: Fine-grained sandstones showing climbing ripple cross-lamination (facies 2). The sandstones are closely associated with laminated mudstones and parallel-laminated sandstones and represent low-density turbidites. Scale is $10 \mathrm{~cm}$ long.

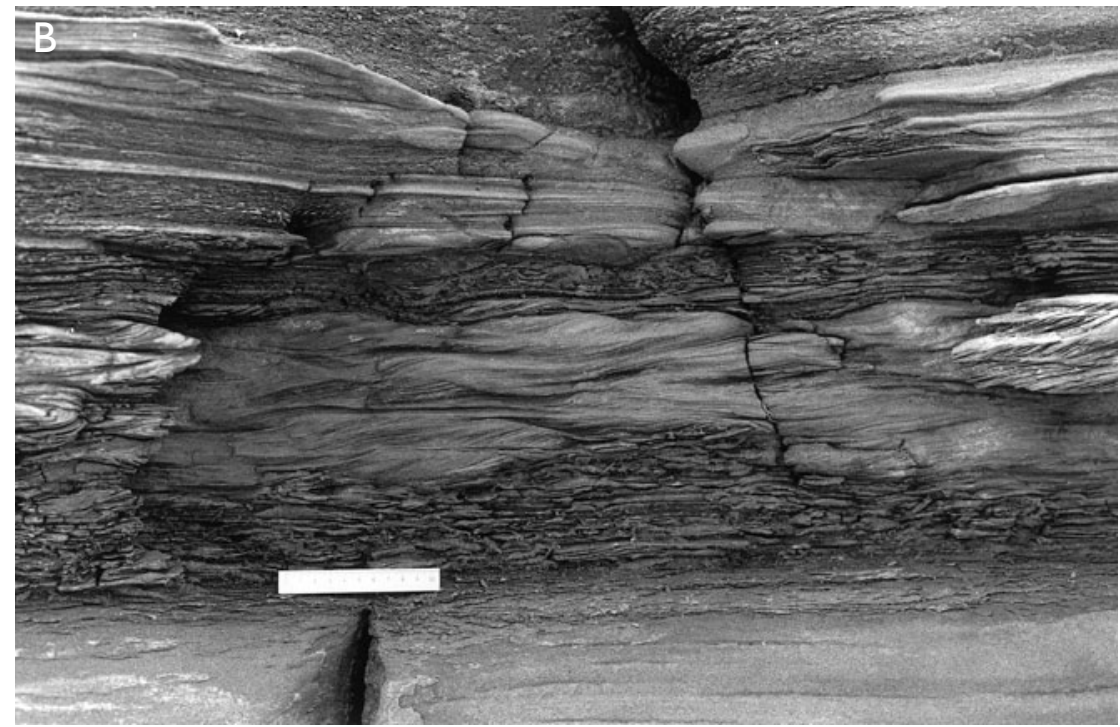

\section{Facies 1. Laminated mudstones}

The facies consists of dark brown or dark grey to black, micaceous, silty and sandy mudstones. They are generally well-laminated although the lamination is commonly disrupted by bioturbation. At some levels, the facies is heterolithic with alternating very fine-grained sandstone and mudstone laminae giving the facies a striped appearance (Fig. 5A). Locally the sandstone laminae pinch and swell with incipient ripple formsets some of which show cross-lamination. Helminthoida isp. grazing or crawling traces occur in high densities on bedding planes. The mudstones have a total organic carbon (TOC) content of 1-9\% and a total sulphur (TS) content of $0.1-1.3 \%$. The highest TOC value is shown by a black finely laminated mudstone $2 \mathrm{~m}$ above the base of the Hades Member (Fig. 2, section 3, $78 \mathrm{~m}$ ).
Carbonate concretions are common and form isolated lenses or lensoid layers. They have nuclei of fossil wood and, in a few cases, ammonites. The mudstones contain rare belemnites, bivalves and ammonites. A marine, low diversity dinoflagellate cyst assemblage was described by Fensome (1979).

Facies 1 is dominated by fine-grained sediment deposited from suspension. Intervals of ripple cross-laminated siltstones and fine sandstones, however, indicate traction current action representing low-energy turbidity currents or weak bottom currents.

Facies 2. Cross-laminated sandstones

The facies consists of well-sorted, very fine- or finegrained current ripple cross-laminated sandstone. Set 
thickness normally varies from $0.5-2 \mathrm{~cm}$, but may reach $4 \mathrm{~cm}$. Asymmetric ripple-formsets and climbing-ripple cross-lamination occur locally (Fig. 5B). Ripple asymmetry and orientations of foresets indicate a south to south-easterly palaeocurrent direction (Fig. 4). The facies forms sandstone-dominated packages with gradational boundaries to facies 1 .

The rippled sandstones were deposited from low-density turbidity currents (Bouma 1962) or weak bottom currents. The close association with mudstones of facies 1 suggests that the cross-laminated sandstones were deposited in a deep-water environment with only episodic sand deposition.

\section{Facies 3. Parallel-laminated sandstones}

The facies is composed of well-sorted, very fine-grained or fine-grained sandstones forming beds up to $60 \mathrm{~cm}$ thick. These beds show marked lateral changes in thickness from a few centimetres to $60 \mathrm{~cm}$ over a few tens of metres, and pinch-and-swell morphology is common. The thicker beds show parallel and low angle hummocky-like stratification associated with soft-sediment deformation structures including overturned folds. Antidune lamination showing aggradation on the upslope side of low-angle bedforms and draping of previous topography by parallel-laminated sandstones is also represented. The parallel-laminated sandstones mainly have flat bases, but scouring occurs locally. The erosional topography is filled by laminated sandstones with divergent laminae thickening over the deepest part of the scour depressions.
Facies 3 is interpreted as having been deposited from low density turbidity currents ( $\mathrm{T}_{\mathrm{b}}$ division; Bouma 1962). Some of the structures show a superficial resemblance to hummocky cross-stratification, but are interpreted as having been formed in the upper flow regime with plane bed deposition transitional to antidune bedding (Skipper 1971; Hand et al. 1972; Prave \& Duke 1990).

\section{Facies 4. Massive sandstones}

The facies consists of white to light grey, micaceous, fine- to medium-grained well sorted, massive sandstone beds commonly with a slightly graded, parallel-laminated top rich in disseminated plant material. Two subfacies are recognised.

\section{Subfacies 4a. Sheet-like massive sandstones}

The subfacies includes sheet-like units of massive sandstones, up to $8 \mathrm{~m}$ thick, built up of amalgamated beds 0.5-2 $\mathrm{m}$ thick, or occasionally comprising single beds. The lower boundaries of the sandstone sheets are sharp, but typically flat and apparently non-erosional (Fig. 6). The sandstone beds in general show parallel boundaries, but emplacement folds and local scouring sometimes occur at amalgamation surfaces (Fig. 7A; Heller \& Dickinson 1985). The individual sandstone beds are massive with grading in the uppermost few centimetres. The graded tops are rich in disseminated, carbonaceous plant material and commonly show deformation by water-escape and loading (Fig. 7B). Amalgamated beds may split into separate beds over a distance of a

Fig. 6. Sheet-like units of amalgamated, massive, fine-grained sandstone beds (facies 4a) interbedded with mudstonedominated intervals (facies 1-3) in the Athene Member. Note the sharp but apparently non-erosional lower boundary of the sandstones (arrows). The white sandstone bed in the centre of the photo is $8 \mathrm{~m}$ thick. Section $1,15-40 \mathrm{~m}$ above base of Athene Member (Fig. 4).

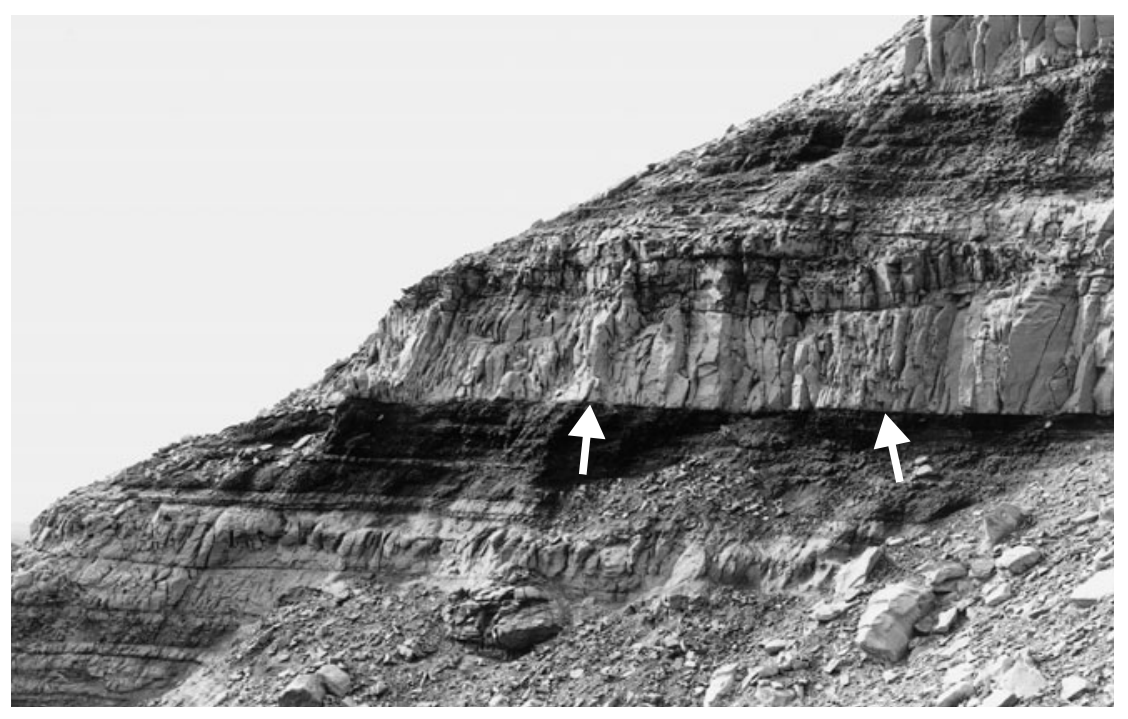



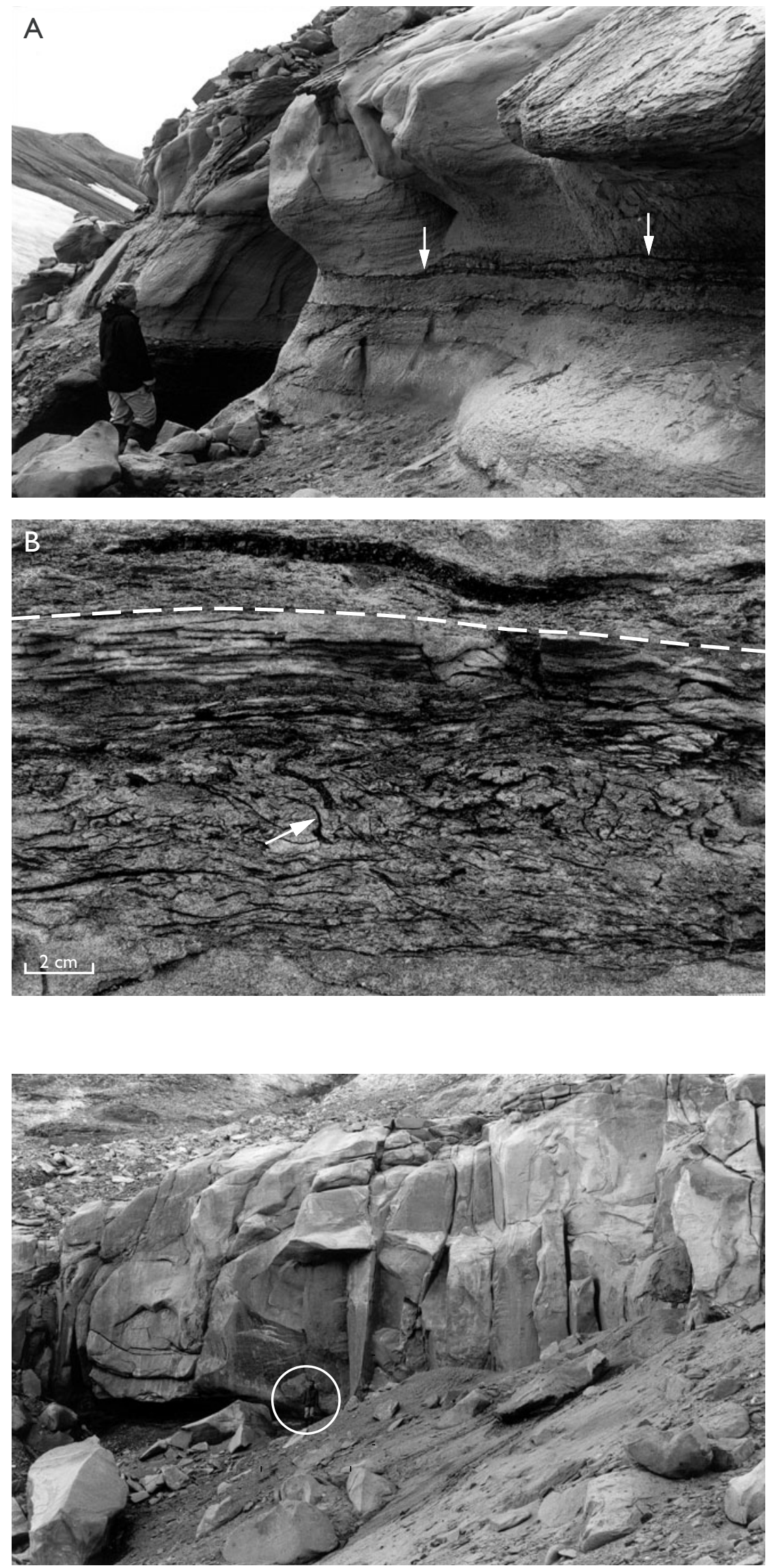

Fig. 7. A: Amalgamated, massive, finegrained sandstone beds separated by thin carbonaceous levels in the lower part of the Athene Member (facies 4a). Note the truncation of the lower beds in the centre of the photograph (arrows). Person for scale. B: Top of a massive sandstone bed (facies 4). Note the horizon of carbonaceous plant material showing flow structures (arrow) overlain by parallel-laminated fine-grained sandstones. The top part shows a concentration of low-density organic material and the upwards change in structures suggest deposition from the waning phase of a turbidity current. The sharp base of the overlying bed is indicated by a dashed line. Section 3 .
Fig. 8. Massive sandstone bed (facies 4), $12 \mathrm{~m}$ thick, forming the top of the Athene Member. The massive nature of the sandstone suggests deposition from either a sandy debris flow or a sustained high-density turbidity current. Section 5; person (encircled) for scale. 
Fig. 9. Gully fill (facies 4b) at the top of the middle unit (sections 7-9). A: Large slab of mudstone lifted by intrusive sand at the base of the gully. The left side of the slab is partly in situ, whereas the right side is lifted and truncated.

B: Mudstone rip-up clast in the lower part of the gully fill sandstone. Note the sharp lower boundary of the sandstone (arrows); hammer for scale.
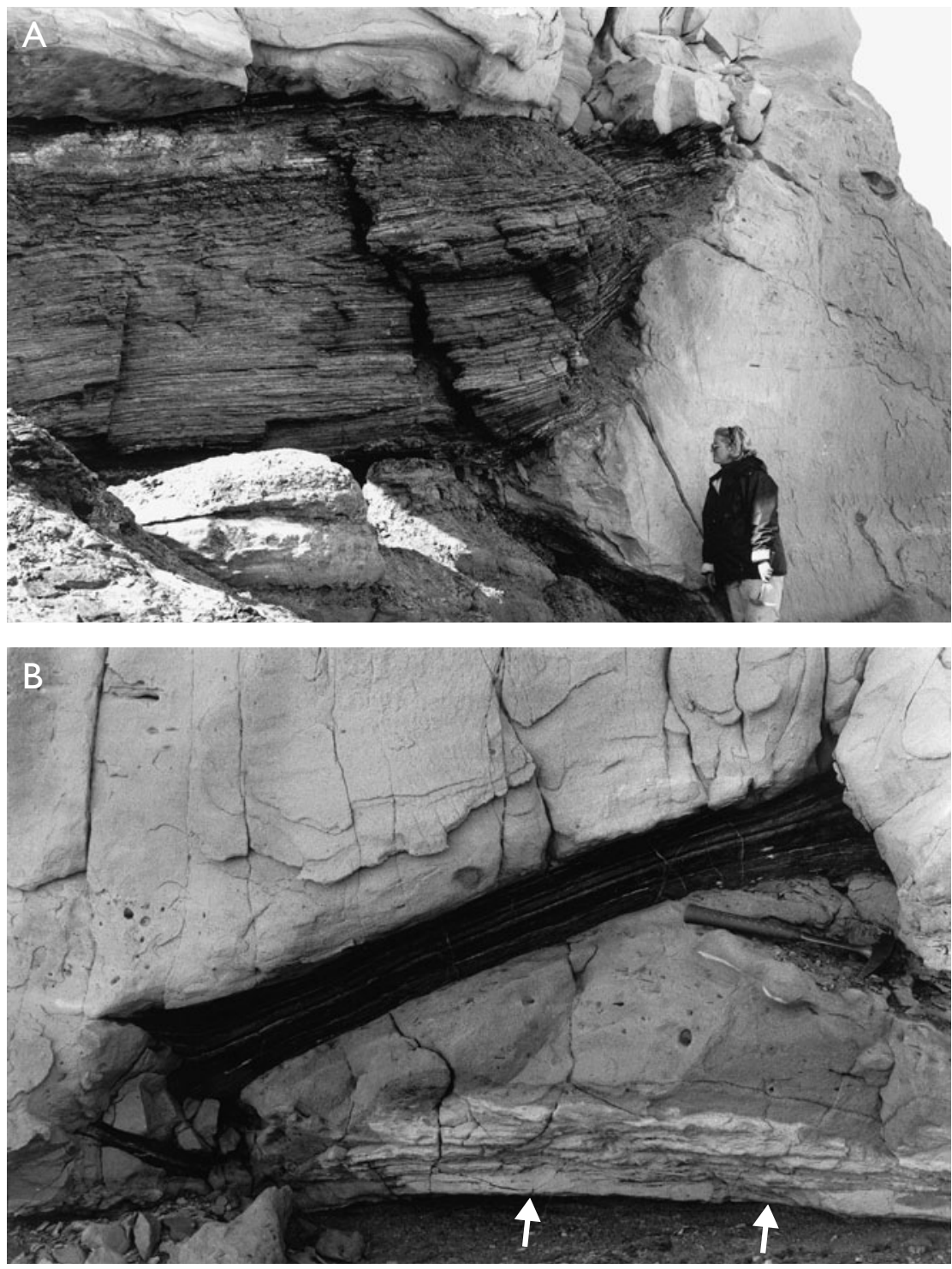

few hundred metres. Pyrite concretions, up to $3 \mathrm{~cm}$ in diameter, are common along the lower bed boundaries. In the upper part of the sandstone-dominated Athene Member, an up to $17 \mathrm{~m}$ thick massive sandstone bed is referred to facies $4 \mathrm{a}$ (Fig. 8). The base of the bed shows evidence of loading, but only minor erosion.

The massive sandstones are interpreted as the deposits of sediment gravity flows, either turbidity currents or sandy debris flows (Lowe 1982; Surlyk 1987; Kneller \& Branney 1995). The graded tops with abundant carbonaceous plant material, however, suggest deposition from turbidity currents. This implies that the thick, ungraded part of each bed was probably formed by gradual aggradation of sand beneath a sustained steady or quasi-steady current (Kneller \& Branney 1995). The largely planar and parallel lower and upper bed boundaries indicate that the flows were in a largely non-erosive stage and deposition probably occurred in a base-of-slope and basin floor setting (Heller \& Dickinson 1985). The thicker beds commonly consist of amalgamated units, as indicated by horizons of carbonaceous plant material. Emplacement folds between amalgamated sandstones suggest that the sands of the upper bed were emplaced upon the still largely unconsolidated substratum of the underlying bed (Heller \& Dickinson 1985). The common occurrence of packets of amalgamated sandstones separated by thick mudstone units suggests that sandstone deposition occurred in discrete pulses separated by longer periods of background sedimentation of fines. 


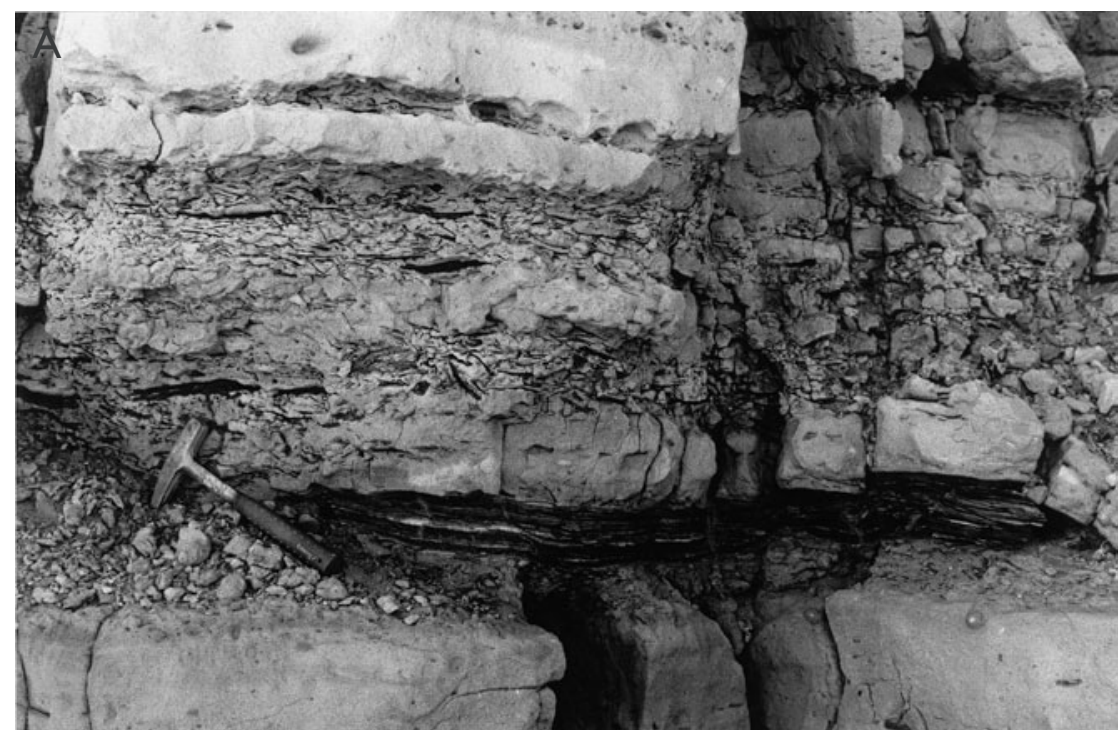

Fig. 10. A: Zones with aligned mudstone clasts in the lower part of the gully fill indicate that deposition occurred in pulses or as separate flows that followed shortly after one another. B: Several metres thick unit of parallel-laminated fine-grained sandstones forming the top part of the gully fill, section 7. Hammer (centre right) for scale.

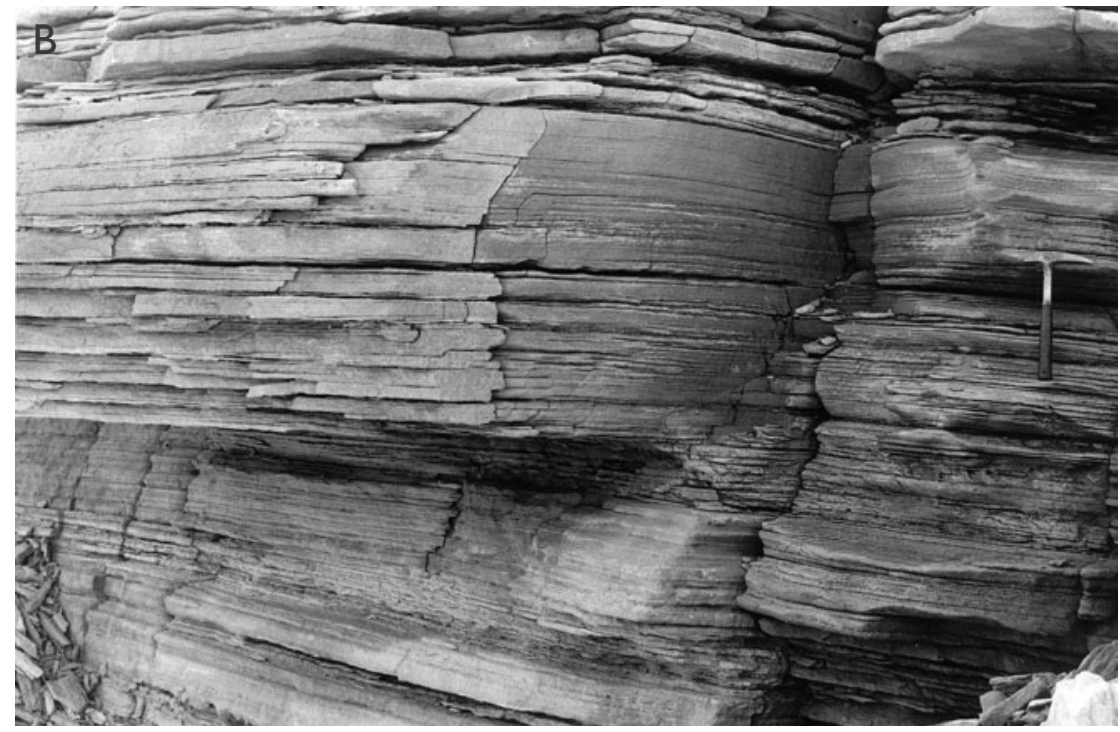

\section{Subfacies $4 \mathrm{~b}$. Lenticular massive sandstones}

The subfacies consists of lenticular sandstone bodies, up to $16 \mathrm{~m}$ thick, that fill deep erosional scours or gullies several tens of metres wide in cross-section. The most spectacular example occurs in the upper part of the Hades Member (Fig. 4, section 7). At this locality, a large slab of mudstone is partially detached, and truncated by massive sands at the base of the gully fill (Fig. $9 \mathrm{~A})$. The sandstone fill is massive, fine- to medium-, or locally coarse-grained, and shows normal grading in the lower levels and at the top. Floating well-rounded, oblate quartzite pebbles occur in the lower levels of one thick gully fill (Fig. 2, section 7, $30 \mathrm{~m}$ ). Mudstone clasts ranging from a few millimetres to several metres in largest dimension occur scattered or in distinct horizons
(Fig. 9B). The larger clasts are found relatively close to the base of the sandstone beds. The mudstone clasts are commonly undeformed except for torn-up ends (Fig. 10A), but sheared clasts occur along the lower margins of some beds. The axis of the gully exposed in section 7 strikes NW-SE $\left(137^{\circ}\right)$. The massive sandstones grade upwards into parallel-laminated sandstones from a few centimetres to several metres thick, capped by cross-laminated sandstones (Fig. 10B).

The massive sandstone bodies were emplaced by sediment gravity flows (Lowe 1982; Kneller \& Branney 1995). The basal grading and the upwards change into parallel-laminated sandstones suggest deposition from sustained high-density turbidity currents (Kneller \& Branney 1995) although a sandy debris flow origin is also possible. Horizons of mudstone intraclasts may mark the for- 
Fig. 11. Cross-bedded, coarse-grained sandstones (facies 6) of the Zeus Member. Individual sets are up to $3 \mathrm{~m}$ thick (locally up to $6 \mathrm{~m}$ ), and are separated by heterolithic mudstones and fine-grained sandstones. Foresets are commonly tangential with strongly bioturbated toesets and truncated topsets. Section 3 .

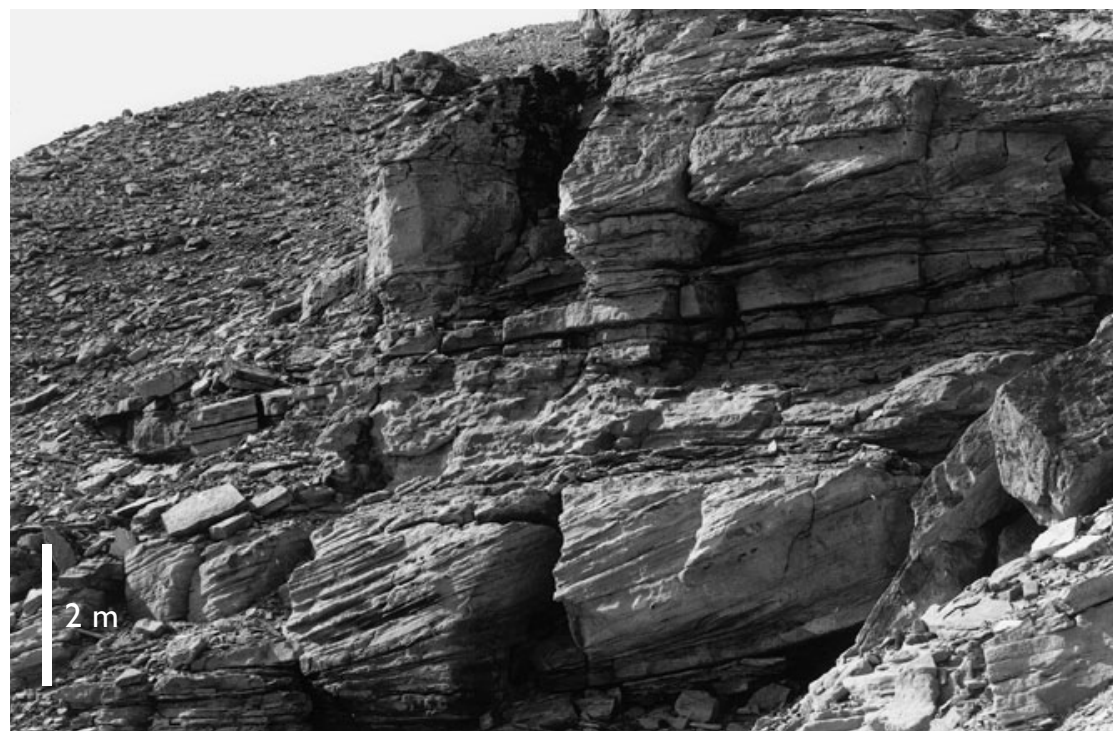

mer position of the rising depositional flow boundary or may, in some cases, show the presence of thinner depositional units separated by subhorizontal amalgamation surfaces. The shape of the clasts shows that the adjacent mudstones were cohesive or partly consolidated at the time of gully erosion and sandstone deposition.

\section{Facies 5. Trough cross-bedded sandstones}

The facies consists of trough cross-bedded, mediumto coarse-grained sandstones with sets $10-15 \mathrm{~cm}$ thick, forming cosets up to $1.5 \mathrm{~m}$ thick. Trough axes indicate palaeocurrent directions towards the south-east. Bioturbation is common and includes Diplocraterion habichi and Skolithos isp. The facies is confined to the Zeus Member (Fig. 2). The trough cross-sets are commonly located at the down-current termination of lenticular bodies of large-scale cross-bedded sandstones of facies 6 .

The facies was deposited by traction currents in the upper part of the lower flow regime. The trace fossil assemblage suggests a shallow marine environment.

\section{Facies 6. Large-scale cross-bedded sandstones}

The facies consists of coarse-grained sandstones showing large-scale cross-bedding with tangential, locally sigmoidal foresets (Fig. 11). The thickness of the crossbeds varies from $0.4-6 \mathrm{~m}$, but is mainly $2-4 \mathrm{~m}$. The crosssets are composed of graded avalanche foresets that reach maximum dips of $26^{\circ}$. They pass downwards into carbonaceous, strongly bioturbated toesets. Double mud drapes are found locally in the sandstones, but no systematic changes were recorded in foreset thicknesses. The cross-sets are commonly truncated at the top and are overlain by trough cross-bedded sandstones. In the upper part of the Zeus Member, wave-rippled topsets occur. Dip azimuths of foresets indicate unimodal palaeocurrent directions towards the south with a vector mean of $191^{\circ}$ (Fig. 4). Bioturbation is concentrated along set boundaries and shows high density and diversity. The trace fossil assemblage includes horizontal burrows of Planolites isp., Taenidium serpentinum, Gyrochorte comosa, vertical burrows of Diplocraterion habichi, Skolithos isp. and the resting trace Piscichnus ?kulindrichnus. The facies is only present in the Zeus Member (Fig. 2). The large-scale cross-sets may pass downcurrent into trough cross-bedded sandstones of facies 5 .

The cross-beds were formed by southwards progradation of subtidal sand bodies, the top of which were periodically exposed to wave reworking indicating a water depth around wave base. Comparison with similar facies in the Volgian Raukelv Formation of southern Jameson Land (Surlyk \& Noe-Nygaard 1991) suggests that the cross-beds may form intrasets in large-scale compound foreset beds.

\section{Facies successions}

The facies of the Olympen Formation form an overall progradational megacycle that is made up of two shallowing-upwards cycles: (1) the uppermost Fossilbjerget Formation together with the Athene Member and (2) 
the Hades and Zeus Members of the Olympen Formation (Fig. 2). They are described in turn and interpreted within the framework of the delta-fed turbidite ramp model of Heller \& Dickinson (1985) and Surlyk (1987).

\section{Lower cycle}

The lower shallowing-upwards cycle is formed by the silty mudstones of the uppermost part of the Fossilbjerget Formation and the sharp-based, mainly massive sandstones (facies 4) intercalated with mudstones (facies 1) and fine-grained sandstones (facies 2 and 3) forming the Athene Member (Fig. 2). The first sandstone bed is $4 \mathrm{~m}$ thick and abruptly overlies a uniform succession of silty mudstones, several tens of metres thick. Above this level, massive sandstones of facies 4 dominate volumetrically. They are commonly amalgamated and may form units up to $17 \mathrm{~m}$ thick, whereas single beds may reach $8 \mathrm{~m}$ in thickness. The laterally persistent sheetlike beds of massive sandstone (facies 4a) dominate the lower part of the cycle, whereas the upper part of the cycle is characterised by thick, lenticular sandstones (facies 4b). A few beds of ripple cross-laminated sandstones (facies 2) and parallel-laminated sandstones (facies 3) are intercalated with mudstone units in the middle part of the cycle. The mudstones change from non-bioturbated to bioturbated c. $20 \mathrm{~m}$ above the base of the first sandstone bed.

A marked change in facies occurs at the transition to the overlying mudstone-dominated association of the Hades Member and the top of the uppermost massive sandstone bed has been reworked into low-angle inclined sets. At locality 4 (Fig. 4), an isolated cross-bedded coarse-grained sandstone bed is intercalated in mudstones, c. $2 \mathrm{~m}$ above the base of the upper cycle. The sandstones at the top of the lower cycle are intensively bioturbated and show a diverse trace fossil assemblage compared to the underlying sandstones.

\section{Upper cycle}

The base of the upper cycle is marked by a sharp boundary between sandstones at the top of the Athene Member and dark silty mudstones of the Hades Member (facies 1; Figs 2, 4). The mudstone-dominated lower portion is about $50 \mathrm{~m}$ thick and shows a slight coarsening-upwards trend in the upper $15 \mathrm{~m}$. The most finegrained mudstones occur at $1.5 \mathrm{~m}$ and $6 \mathrm{~m}$ above the base of the cycle and are black, organic-rich (9\% TOC) and finely laminated. With these exceptions, the micarich mudstones are typically silty, locally sandy and intensely bioturbated. At locality 7 (Fig. 4), the mudstones are succeeded by about 16 m of massive, fine- to mediumgrained sandstones (facies $4 \mathrm{~b}$ ), which fill a deep erosional scour or gully cut into the mudstones (Figs 4, 9).

Elsewhere, the mudstone succession is sharply overlain by a coarse-grained sandstone succession composed of stacked sets of large-scale cross-bedded sandstones (facies 6), trough cross-bedded sandstones (facies 5) and intercalated mudstones (facies 1; Figs 2, 4). Channelling and scouring are common. The coarse-grained sandstones are strongly bioturbated and show a diverse trace fossil assemblage. In the uppermost part of section 3 (Fig. 4), wave-ripple formsets are common on the upper bedding planes of large-scale cross-sets. The uppermost part of the upper cycle is poorly exposed. Isolated outcrops suggest, however, that the coarsegrained cross-bedded sandstone facies continues to the top of the formation.

\section{Depositional model for the Olympen Formation}

The lower cycle represents Late Callovian progradation of a proximal basin and base-of-slope setting. The dominance of laterally continuous, massive, non-erosional gravity flow sandstones (facies $4 \mathrm{a}$ ), and the lack of obvious vertical organisation of the sandstones suggest that they represent a proximal ramp facies of a deltafed turbidite system (Heller \& Dickinson 1985; Surlyk 1987). The shallow marine part of the delta front did not reach the present outcrop area and the interpretation is thus based on comparison with the upper cycle and with shelf-edge deltas and redeposited mass-flow sandstones of the Volgian Raukelv Formation (Surlyk \& Noe-Nygaard 1995). The abrupt incoming of sandstones in the basin plain facies contrasts with the model of Heller \& Dickinson (1985), which predicts a gradual increase in bed thickness and grain size from the basin plain - distal ramp facies to the proximal ramp. The concentration of pyrite concretions in the lower part of the cycle and the upwards change towards more bioturbated sediments suggests a change from a poorly oxygenated deeper-water setting into a more well-aerated, relatively shallow-water environment.

A major drowning event occurred in latest Callovian - Early Oxfordian times before the inferred shelf-edge delta of the lower cycle had reached the area of present-day outcrop. This was followed by renewed progra- 
dation in the Early-Middle Oxfordian. The relatively great thickness of the Lower Oxfordian basinal mudstones, which form the lower $50 \mathrm{~m}$ of the upper progradational cycle, suggests that the drowning event had translated the shelf edge far northwards. At Olympen, shelf-edge delta progradation was heralded by the incoming of thick amalgamated slope sandstones with a strongly scoured base. They were probably deposited in a slope gully of the same type as described from the Upper Oxfordian part of the Hareelv Formation further south in Jameson Land (Surlyk 1987; Surlyk \& NoeNygaard 2001). Finally the shelf-edge delta reached the outcrop area as marked by the incoming of coarsegrained high-angle cross-beds. Such beds are characteristic of lowstand deltas that prograded to the edge of the shelf in the Middle Jurassic (Pelion Formation; Engkilde \& Surlyk 2003, this volume) and especially in the Volgian (Raukelv Formation; Surlyk \& Noe-Nygaard 1991, 1995; Surlyk et al. 1993; Surlyk 2003, this volume).

\section{Sequence stratigraphy}

A sequence stratigraphic interpretation of the Olympen Formation is not straightforward due to the relatively deep-water nature of most of the succession. The mudstones at the base of the lower cycle represent Late Callovian maximum flooding of the whole Jameson Land Basin. The delta top of the lower unit is not preserved in Jameson Land. The slope and base-of-slope mass-flow sandstones were most likely deposited during late fall, maximum lowstand or early rise. Thus, the base of the lower sandstone package may not necessarily represent the time of maximum sea-level lowstand and the correlative surface to the subaerial sequence boundary could be found within the sandstone package (Hunt \& Tucker 1993, 1995). However, it has not been possible to define this deep-water correlative surface in the succession and present-day exposures do not allow tracing of the surface from the basin margin into the slope system. In our view, the sandstone succession is thus best interpreted as an undifferentiated falling stage and lowstand systems tract (Fig. 4).

The drowning surface at the top of the lower cycle is interpreted to represent the slope correlative of the transgressive surface defining the top of the lowstand systems tract. It probably passes up-dip into a ravinement surface, which extended across the inner shelf to the north.

The thin organic-rich mudstone unit in the basal part of the second cycle represents the maximum flooding zone overlying a transgressive systems tract which is only a few metres thick (Fig. 4). It is overlain by a thick coarsening-upwards mudstone-dominated highstand systems tract. The incoming of massive sandstones indicates that the delta had prograded to the shelf edge, and massive sands were shed down the slope from the delta front. The sharp base of the overlying cross-bedded delta front sandstones was possibly formed by marine erosion in front of the prograding delta and may represent a marine regressive surface of erosion (Posamentier et al. 1992). The cross-bedded delta front sandstones (Fig. 4) are thus tentatively placed in the falling stage systems tract (Hunt \& Tucker 1993, 1995; Nummedal et al. 1993).

\section{Comparison with eustatic sea-level curves}

Since the seminal work of Vail et al. (1977; see Miall 1997 for an overview), the validity of global sea-level curves has been extensively debated. However, as data from different regions are added and the dating of observed sea-level changes is refined, portions of the curve may prove to be eustatic. A regional sea-level curve for the Jurassic of East Greenland was presented by Surlyk (1990) and compared with the eustatic curves of Haq et al. (1988) and Hallam (1988).

Sea-level changes based on the sequence stratigraphic interpretation of the Olympen Formation can be tied to ammonite chronozones and allow refinement of the regional sea-level curve for the late Middle and early Late Jurassic of the Jameson Land Basin of East Greenland (Fig. 12). The Late Jurassic part of the curve is supplemented with data from the Charcot Bugt Formation in Milne Land situated at the western margin of the East Greenland basin (Larsen 1995; Larsen et al. 2003, this volume).

The sea-level changes recorded in the Olympen Formation include a sea-level rise in the Middle Callovian (K. jason Chron), a Late Callovian fall (early-middle $P$. athleta and possibly Q. lamberti Chrons), an end Callovian - Early Oxfordian rise (Q. mariae Chron) and a late Early - Middle Oxfordian fall ( $C$. densiplicatum Chron) (Fig. 12). These changes can be matched closely with a proposed eustatic sea-level curve for the central part of the Russian Platform (Sahagian et al. 1996). The Callovian part of the curve does not match the sealevel curve of Haq et al. (1988), whereas the Early Oxfordian rise followed by Middle Oxfordian fall is recorded in all three curves (Fig. 12). 


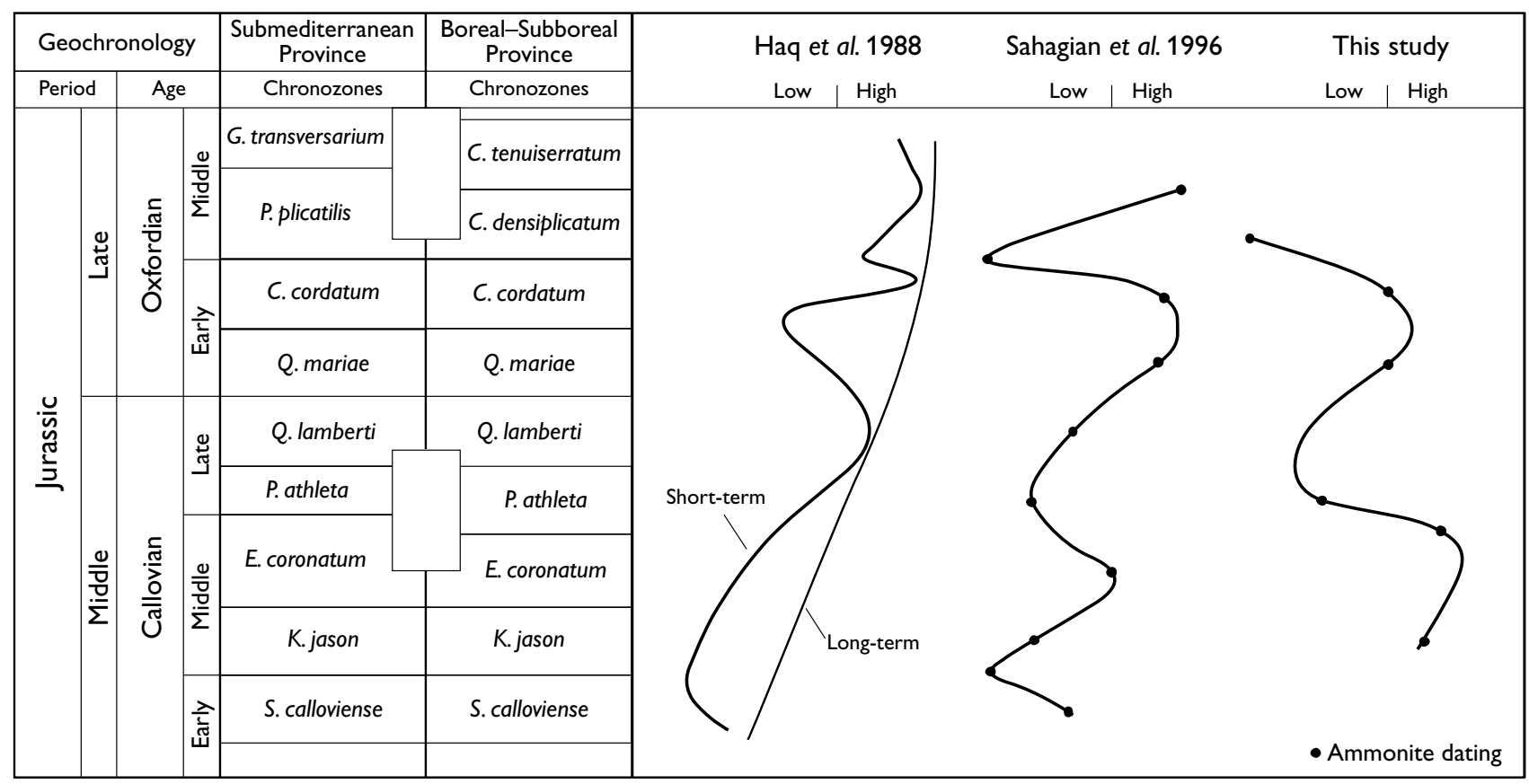

Fig. 12. Comparison of sea-level curves for the Callovian-Oxfordian time interval based on the data in this study (East Greenland), Haq et al. (1988) (global) and Sahagian et al. (1996) (Russian platform). Note the close correlation between short-term changes in the East Greenland and Russian platform curves. Amplitudes of the curves have been rescaled for illustration purposes. Ammonite zonation based on Sykes \& Callomon (1979) and Callomon (2003, this volume).

\section{Conclusions}

The Upper Bajocian - Upper Volgian succession in the Jameson Land Basin, East Greenland forms a long-term transgressive-regressive cycle with maximum flooding in the Middle Callovian and Early Kimmeridgian and regressive pulses in the Late Callovian, and the Middle and Late Oxfordian. The Upper Callovian - Middle Oxfordian Olympen Formation represents the initial regression following Middle Callovian flooding. The formation consists of a tripartite sandstone-mudstone-sandstone package overlying Upper Callovian mudstones of the Fossilbjerget Formation. The top of the Fossilbjerget Formation and the lower sandstone-dominated Athene Member of the Olympen Formation together record Late Callovian progradation of the shelf-edge delta and slope towards the south. The delta top did not reach the area of present-day exposure, however, and the sandstone unit consists solely of massive gravity flow sandstones deposited on the slope and base-of-slope.

Progradation was terminated by a major Early Oxfordian drowning event. Renewed progradation took place in the Early-Middle Oxfordian heralded by slight coarsening-upwards of the Hades Member mudstones and the formation of erosional slope gullies filled with massive gravity flow sandstones, tens of metres thick. They are directly overlain by delta front and coarse-grained, cross-bedded delta top sandstones of the Zeus Member indicating that the delta finally reached the area.

The Athene Member of the Olympen Formation represents an undifferentiated falling stage - lowstand systems tract. The drowning surface at the top of the Athene Member is interpreted as the top lowstand surface forming the distal correlative of the transgressive surface. A maximum flooding zone is recognised in the basal part of the mudstones of the Hades Member, followed by a thick, coarsening-upwards mudstone succession with lenticular bodies of massive sandstones representing the highstand systems tract. The sharp base of the overlying cross-bedded delta front sandstones of the Zeus Member is interpreted to represent a marine regressive surface of erosion, and the sandstones are tentatively placed in a falling stage systems tract.

Comparison of this history of Middle Callovian maximum flooding ( $K$. jason Chron), Late Callovian fall (early-middle P. atbleta and possibly $Q$. lamberti Chrons), latest Callovian - Early Oxfordian flooding (Q. mariae Chron) and late Early - Middle Oxfordian (C. densiplicatum Chron) regression with published eustatic sea-level curves suggests that the short-term changes can be matched within the resolution of ammonite zones. 


\section{Acknowledgements}

M.L. gratefully acknowledges a three-year Ph.D. stipend from the Carlsberg Foundation (91-0683/20, 92-0505/20 and 93-0735/20). The Danish Natural Science Research Council supported subsequent work. We wish to thank Michael Engkilde and John H. Callomon for sedimentological and stratigraphic discussions and the referees, Stephen P. Hesselbo, Kevin T. Pickering and Duncan Pirrie, for their thorough reviews and suggestions to improve the manuscript.

\section{References}

Birkelund, T., Håkansson, E. \& Surlyk, F. 1971: New finds of Bathonian, Callovian and Oxfordian ammonites in northern Jameson Land, East Greenland. Bulletin of the Geological Society of Denmark 20, 240-259.

Bouma, A.H. 1962: Sedimentology of some flysch deposits: a graphic approach to facies interpretation, $168 \mathrm{pp}$. Amsterdam: Elsevier.

Callomon, J.H. 1993: The ammonite succession in the Middle Jurassic of East Greenland. Bulletin of the Geological Society of Denmark 40, 83-113.

Callomon, J.H. 2003: The Middle Jurassic of western and northern Europe: its subdivisions, geochronology and correlations. In: Ineson, J.R. \& Surlyk, F. (eds): The Jurassic of Denmark and Greenland. Geological Survey of Denmark and Greenland Bulletin 1, 61-73 (this volume).

Engkilde, M. \& Surlyk, F. 2003: Shallow marine syn-rift sedimentation: Middle Jurassic Pelion Formation, Jameson Land, East Greenland. In: Ineson, J.R. \& Surlyk, F. (eds): The Jurassic of Denmark and Greenland. Geological Survey of Denmark and Greenland Bulletin 1, 813-863 (this volume).

Fensome, R.A. 1979: Dinoflagellate cysts and acritarchs from the Middle and Upper Jurassic of Jameson Land, East Greenland. Bulletin Grønlands Geologiske Undersøgelse 132, 98 pp.

Gensous, B. \& Tesson, M. 1996: Sequence stratigraphy, seismic profiles, and cores of Pleistocene deposits on the Rhone continental shelf. Sedimentary Geology 105, 183-190.

Hallam, A. 1988: A reevaluation of Jurassic eustasy in the light of new data and the revised Exxon curve. In: Wilgus, C.K. et al. (eds): Sea-level changes - an integrated approach. Society of Economic Paleontologists and Mineralogists Special Publication 42, 261-273.

Hand, B.M., Middleton, G.V. \& Skipper, K. 1972: Antidune crossstratification in a turbidite sequence, Cloridorme Formation, Gaspé, Quebec. Sedimentology 18, 135-138.

Haq, B.U., Hardenbol, J. \& Vail, P.R. 1988: Mesozoic and Cenozoic chronostratigraphy and cycles of sea-level change. In: Wilgus, C.K. et al. (eds): Sea-level changes - an integrated approach. Society of Economic Paleontologists and Mineralogists Special Publication 42, 71-108.

Heller, P.L. \& Dickinson, W.R. 1985: Submarine ramp facies model for delta-fed, sand-rich turbidite systems. American Association of Petroleum Geologists Bulletin 69, 960-976.

Henriksen, S. \& Weimer, P. 1996: High-frequency depositional sequences and stratal stacking patterns in Lower Pliocene coastal deltas, Mid-Norwegian continental shelf. American Association of Petroleum Geologists Bulletin 80, 1867-1895.

Hunt, D. \& Tucker, M.E. 1993: Sequence stratigraphy of carbonate shelves with an example from the mid-Cretaceous (Urgonian) of southeast France. International Association of Sedimentologists Special Publication 18, 307-341.

Hunt, D. \& Tucker, M.E. 1995: Stranded parasequences and the forced regressive wedge systems tract: deposition during baselevel fall - reply. Sedimentary Geology 95, 147-160.

Kneller, B.C. \& Branney, M.J. 1995: Sustained high-density turbidity currents and the deposition of thick massive sands. Sedimentology 42, 607-616.

Larsen, M. 1995: Facies architecture and sequence stratigraphy of basement-onlapping shallow marine sandstones of the Charcot Bugt Formation, Middle Jurassic, East Greenland, 1, 121 pp. Unpublished Ph.D. thesis, University of Copenhagen, Denmark

Larsen, M., Piasecki, S. \& Surlyk, F. 2003: Stratigraphy and sedimentology of a basement-onlapping shallow marine sandstone succession, the Charcot Bugt Formation, Middle-Upper Jurassic, East Greenland. In: Ineson, J.R. \& Surlyk, F. (eds): The Jurassic of Denmark and Greenland. Geological Survey of Denmark and Greenland Bulletin 1, 893-930 (this volume).

Lowe, D.R. 1982: Sediment gravity flows: II. Depositional models with special reference to the deposits of high-density turbidity currents. Journal of Sedimentary Petrology 52, 279-297.

Miall, A.D. 1997: The geology of stratigraphic sequences, 433 pp. Berlin Heidelberg: Springer-Verlag.

Nummedal, D., Riley, G.W. \& Templet, P.L. 1993: High-resolution sequence architecture: a chronostratigraphic model based on equilibrium profile studies. International Association of Sedimentologists Special Publication 18, 55-68.

Posamentier, H.W., Allen, G.P., James, D.P. \& Tesson, M. 1992: Forced regressions in a sequence stratigraphic framework; concepts, examples and exploration significance. American Association of Petroleum Geologists Bulletin 76, 1687-1709.

Prave, A.R. \& Duke, W.L. 1990: Small-scale hummocky crossstratification in turbidites: a form of antidune stratification? Sedimentology 37, 531-539.

Sahagian, D., Pinous, O., Olferiev, A. \& Zakharov, V. 1996: Eustatic curve for the Middle Jurassic - Cretaceous based on Russian Platform and Siberian stratigraphy: zonal resolution. American Association of Petroleum Geologists Bulletin 80, 1433-1458.

Skipper, K. 1971: Antidune cross-stratification in a turbidite sequence, Cloridorme Formation, Gaspé, Quebec. Sedimentology 17, 51-68.

Surlyk, F. 1987: Slope and deep shelf gully sandstones, Upper Jurassic, East Greenland. American Association of Petroleum Geologists Bulletin 71, 464-475.

Surlyk, F. 1990: A Jurassic sea-level curve for East Greenland. Palaeogeography, Palaeoclimatology, Palaeoecology 78, 71-85.

Surlyk, F. 1991: Sequence stratigraphy of the Jurassic - lowermost 
Cretaceous of East Greenland. American Association of Petroleum Geologists Bulletin 75, 1468-1488.

Surlyk, F. 2003: The Jurassic of East Greenland: a sedimentary record of thermal subsidence, onset and culmination of rifting. In: Ineson, J.R. \& Surlyk, F. (eds): The Jurassic of Denmark and Greenland. Geological Survey of Denmark and Greenland Bulletin 1, 659-722 (this volume).

Surlyk, F. \& Noe-Nygaard, N. 1991: Sand bank and dune facies architecture of a wide intracratonic seaway: Late Jurassic - Early Cretaceous Raukelv Formation, Jameson Land, East Greenland. In: Miall, A.D. \& Tyler, N. (eds): The three-dimensional facies architecture of terrigenous clastic sediments, and its implications for hydrocarbon discovery and recovery. SEPM (Society for Sedimentary Geology) Concepts in Sedimentology and Paleontology 3, 261-276.

Surlyk, F. \& Noe-Nygaard, N. 1995: High-angle clinoform beds a recurrent architectural element in Jurassic shallow marine deposits of East Greenland. Sedimentary responses to forced regressions: recognition, interpretation and reservoir potential, Geological Society, London, 7-9 September, 1995. Programme with abstracts, 64-65.

Surlyk, F. \& Noe-Nygaard, N. 2001: Sand remobilisation and intrusion in the Upper Jurassic Hareelv Formation of East Greenland. In: Surlyk, F. \& Håkansson, E. (eds): Oscar volume. Bulletin of the Geological Society of Denmark 48, 169-188.

Surlyk, F., Callomon, J.H., Bromley, R.G. \& Birkelund, T. 1973: Stratigraphy of the Jurassic - Lower Cretaceous sediments of Jameson Land and Scoresby Land, East Greenland. Bulletin Grønlands Geologiske Undersøgelse 105, 76 pp.

Surlyk, F., Noe-Nygaard, N. \& Dam, G. 1993: High and low resolution sequence stratigraphy in lithological predictions examples from the Mesozoic around the northern North Atlantic. In: Parker, J.R. (ed.): Petroleum geology of Northwest Europe: proceedings of the 4th conference, 199-213. London:
Geological Society.

Suter, J.R. \& Berryhill, H.L. 1985: Late Quaternary shelf-margin deltas, northwest Gulf of Mexico. American Association of Petroleum Geologists Bulletin 69, 77-91.

Suter, J.R., Berryhill, H.L. \& Penland, S. 1987: Late Quaternary sea level fluctuations and depositional sequences, southwest Louisiana continental shelf. In: Nummedal, D., Pilkey, O.H. \& Howard, J. (eds): Sea-level change and coastal evolution. Society of Economic Paleontologists and Mineralogists Special Paper 41, 199-219.

Sydow, J. \& Roberts, H.H. 1994: Stratigraphic framework of a Late Pleistocene shelf-edge delta, northeast of Mexico. American Association of Petroleum Geologists Bulletin 78, 1276-1312.

Sykes, R.M. \& Callomon, J.H. 1979: The Amoeboceras zonation of the Boreal Upper Oxfordian. Palaeontology 22, 839-903.

Tesson, M., Gensous, B., Allen, G.P. \& Ravenne, C. 1990: Late Quaternary deltaic lowstand wedge on the Rhone continental shelf, France. Marine Geology 91, 325-332.

Tesson, M., Allen, G.P. \& Ravenne, C. 1993: Late Pleistocene shelf-perched lowstand wedges on the Rhone continental shelf. International Association of Sedimentologists Special Publication 18, 183-196.

Underhill, J.R. \& Partington, M.A. 1994: Use of genetic sequence stratigraphy in defining and determining a regional tectonic control on the 'Mid-Cimmerian Unconformity' - implications for North Sea basin development and the global sea-level chart. In: Weimer, P. \& Posamentier, H.W. (eds): Siliciclastic sequence stratigraphy: recent developments and applications. American Association of Petroleum Geologists Memoir 58, 449-484.

Vail, P.R., Mitchum, R.M., Todd, R.G., Widmier, J.M., Thompson, S., Sangree, J.B., Bubb, J.N. \& Hatlelid, W.G. 1977: Seismic stratigraphy and global changes of sea level. American Association of Petroleum Geologists Memoir 26, 49-212. 




\section{Danmarks og Grønlands Geologiske Undersøgelse (GEUS) Geological Survey of Denmark and Greenland Oster Voldgade 10, DK-1350 Copenhagen K Denmark}

Geological Survey of Denmark and Greenland Bulletin is a new series started in 2003 to replace the two former bulletin series of the Survey, viz. Geology of Greenland Survey Bulletin and Geology of Denmark Survey Bulletin. The twenty-one volumes published since 1997 in those two series are listed below, followed by titles in the new bulletin series. The new series, together with Geological Survey of Denmark and Greenland Map Series, now form the peer-review scientific series of the Survey.

\section{Geology of Greenland Survey Bulletin (discontinued)}

173 Cambrian shelf stratigraphy of North Greenland, 120 pp., 1997.

By J.R. Ineson \& J.S. Peel.

174 The Proterozoic Thule Supergroup, Greenland and Canada: history, lithostratigraphy and development, 150 pp., 1997. By P.R. Dawes.

175 Stratigraphy of the Neill Klinter Group; a Lower - lower Middle Jurassic tidal embayment succession, Jameson Land, East Greenland, 80 pp., 1998.

By G. Dam \& F. Surlyk.

176 Review of Greenland activities 1996, 112 pp. (18 articles), 1997 Edited by A.K. Higgins \& J.R. Ineson.

177 Accretion and evolution of an Archaean high-grade grey gneiss - amphibolite complex: the Fiskefjord area, southern West Greenland, 115 pp., 1997. By A.A. Garde.

178 Lithostratigraphy, sedimentary evolution and sequence stratigraphy of the Upper Proterozoic Lyell Land Group (Eleonore Bay Supergroup) of East and North-East Greenland, 60 pp., 1997.

By H. Tirsgaard \& M. Sønderholm.

179 The Citronen Fjord massive sulphide deposit, Peary Land, North Greenland: discovery, stratigraphy, mineralization and structural setting, 40 pp., 1998.

By F.W. van der Stijl \& G.Z. Mosher.

180 Review of Greenland activities 1997, 176 pp. (26 articles), 1998.

Edited by A.K. Higgins \& W.S. Watt.

181 Precambrian geology of the Disko Bugt region, West Greenland, 179 pp. (15 articles), 1999. Edited by F. Kalsbeek.

182 Vertebrate remains from Upper Silurian - Lower Devonian beds of Hall Land, North Greenland, 80 pp., 1999.

By H. Blom.

183 Review of Greenland activities 1998, 81 pp. (10 articles), 1999. Edited by A.K. Higgins \& W.S. Watt.

184 Collected research papers: palaeontology, geochronology, geochemistry, 62 pp. (6 articles), 1999.

185 Greenland from Archaean to Quaternary. Descriptive text to the Geological map of Greenland, 1:2 500 000, 93 pp., 2000.

By N. Henriksen, A.K. Higgins, F. Kalsbeek \& T.C.R. Pulvertaft.

186 Review of Greenland activities 1999, 105 pp. (13 articles), 2000 Edited by P.R. Dawes \& A.K. Higgins.

187 Palynology and deposition in the Wandel Sea Basin, eastern North Greenland, 101 pp. (6 articles), 2000. Edited by L. Stemmerik.

188 The structure of the Cretaceous-Palaeogene sedimentary-volcanic area of Svartenhuk Halvø, central West Greenland, 40 pp., 2000. By J. Gutzon Larsen \& T.C.R. Pulvertaft.

189 Review of Greenland activities 2000, 131 pp. (17 articles), 2001

Edited by A.K. Higgins \& K. Secher. 
190 The Ilímaussaq alkaline complex, South Greenland: status of mineralogical research with new results, 167 pp. (19 articles), 2001.

Edited by $\mathrm{H}$. Sørensen.

191 Review of Greenland activities 2001, 161 pp. (20 articles), 2002.

Edited by A.K. Higgins, K. Secher \& M. Sønderholm.

\section{Geology of Denmark Survey Bulletin (discontinued)}

36 Petroleum potential and depositional environments of Middle Jurassic coals and non-marine deposits, Danish Central Graben, with special reference to the Søgne Basin, 78 pp., 1998.

By H.I. Petersen, J. Andsbjerg, J.A. Bojesen-Koefoed, H.P. Nytoft \& P. Rosenberg.

37 The Selandian (Paleocene) mollusc fauna from Copenhagen, Denmark: the Poul Harder 1920 collection, 85 pp., 2001.

By K.I. Schnetler.

\section{Geological Survey of Denmark and Greenland Bulletin (new series)}

1 The Jurassic of Denmark and Greenland, 948 pp., 2003. Edited by J.R. Ineson \& F. Surlyk.

2 Fish otoliths from the Paleocene of Denmark, 94 pp., 2003. By W. Schwarzhans.

\section{Forthcoming volumes}

Late Quaternary environmental changes recorded in the Danish marine molluscan faunas. By K.S. Pedersen.

The Jurassic of North-East Greenland. Edited by L. Stemmerik \& S. Stouge.

Review of Survey activities, 2003.

Edited by M. Sønderholm \& A.K. Higgins. 

